\title{
PENAPISAN FITOKIMIA DAN UJI TOKSISITAS DARI DAUN Myristica fatua HOUTT
}

\author{
Sofa Fajriah $^{1,2^{*}} \&$ Megawati $^{1}$ \\ ${ }^{1}$ Pusat Peneitian Kimia, LIPI, Kawasan PUSPIPTEK Serpong \\ ${ }^{2}$ Departemen Kimia, FMIPA, UI, Depok \\ *Alamat korespodensi : sofafajriah@gmail.com
}

\begin{abstract}
Abstrak : Myristica fatua merupakan salah satu tumbuhan obat asli Indonesia yang berpotensi untuk dikembangkan. Telah dilakukan penapisan fitokimia dan uji toksisitas menggunakan metode BSLT (Brine Shrimp Lethality Toxicity) terhadap ekstrak metanol, ekstrak aseton dan etanol 70\%. Selanjutnya ekstrak metanol difraksinasi untuk memperoleh fraksi n-heksana, etil asetat, dan n-butanol dari daun Myristica fatua Houtt dan dilakukan uji toksisitas lebih lanjut. Hasil penapisan fitokimia menunjukkan bahwa daun M. fatua mengandung senyawa terpenoid, steroid, flavonoid, saponin, dan tanin. Potensi antikanker juga ditunjukkan terhadap ekstrak metanol dan fraksi etil asetat yang mempunyai toksisitas paling tinggi dari fraksi lainnya dengan LC50 masing-masing adalah sebesar 64,57 dan $83,75 \mu \mathrm{g} / \mathrm{mL}$.
\end{abstract}

Kata kunci : Myristica fatua Houtt, penapisan fitokimia, toksisitas, BSLT

Abstract : Myristica fatua is one of Indonesian natural origin medicinal plant which has potentiality to be developed. Phytochemical screening and toxicity assay of methanol, acetone and $70 \%$ ethanol extracts have been done using BSLT (Brine Shrimp Lethality Toxicity) method. Furthermore, the methanol extract was fractionated to obtain n-hexane, ethyl acetate and n-buthanol fractions from the leaves of Myristica fatua Houtt and further evaluated their toxicity. Phytochemical screening results showed that leaves of M. fatua contain terpenoid, steroid, flavonoid, saponin and tannin compounds. Methanol and ethyl acetate extract showed promising result for anticancer with highest toxicity among the others fractions with LC50 64.57 and $83.75 \mu \mathrm{g} /$ $m L$ respectively.

Keywords: Myristica fatua Houtt, phytochemical screening, toxicity, BSLT

\section{PENDAHULUAN}

Myristicaceae merupakan salah satu suku pantropis. Jenis yang tergolong anggota suku ini umumnya berupa pohon dan berumah dua. Distribusi jenis yang tergolong marga Myristica di seluruh dunia terdapat 175 jenis yang telah dikenal dan terutama ditemukan di India, kawasan Malesiana, Australia Utara dan Fiji di wilayah Pasifik Timur, khusus untuk wilayah Indonesia ditemukan 9 jenis. Myristica fatua merupakan salah satu dari 9 jenis yang berasal dari Indonesia, khususnya di Maluku (Arrijani, 2005).

Tumbuhan pala hutan (Myrisitca fatua Houtt) merupakan salah satu tanaman endemik dari Maluku dan hampir tidak dikenal secara luas. M. fatua secara empirik tidak digunakan sebagai bahan psikoaktif atau rempah seperti halnya pala biasa ( $M$. fragrans). Secara empirik buah pala hutan ini sering digunakan sebagai aprodisiak sehingga dikenal juga dengan nama pala jantan. Selain sebagai aprodisiak, tumbuhan ini juga digunakan sebagai bahan bangunan dan minyaknya sebagai minyak lampu (Jamal \& Agusta, 2004).

Penelitian ini dilakukan untuk mengetahui kandungan golongan senyawa tanaman daun Myristica fatua dengan metode uji penapisan fitokimia, yang merupakan salah satu pendekatan dalam penelitian tumbuhan obat untuk mendeteksi senyawa tumbuhan berdasarkan golongan. Pengujian toksisitas dilakukan dengan metode BSLT (Brine Shrimp Lethality Test), yang merupakan metode skrining awal dalam pengamatan toksisitas suatu ekstrak atau senyawa, dengan menggunakan larva udang Artemia salina Leach sebagai obyek pengamatan, yaitu dengan mengamati tingkat kematian larva udang Artemia salina Leach terhadap ekstrak dari tanaman.

\section{BAHAN DAN METODE PENELITIAN \\ Bahan Tanaman}

Bahan yang digunakan pada penelitian ini adalah daun Myristica fatua Houtt yang diperoleh dari kawasan Hutan Mekongga pada bulan Maret 2014 dan dideterminasi di Herbarium Bogoriense, Pusat Penelitian Biologi LIPI.

\section{Ekstraksi}

Daun kering M. fatua sebanyak $20 \mathrm{~g}$ dimaserasi dengan berbagai pelarut, yaitu metanol, aseton dan etanol $70 \%$ selanjutnya diuji aktivitas toksisitas dengan metode BSLT. Ekstrak yang paling aktif difraksinasi dengan cara ekstraksi cair-cair dan diperoleh fraksi $n$-heksana, etil asetat, dan $n$-butanol. Masing-masing ekstrak selanjutnya diuji aktivitas toksisitas dengan metode BSLT. Untuk skrining fiokimia sampel uji yang digunakan adalah ekstrak metanol daun $M$. fatua. 
Penapisan fitokimia (Depkes RI, 1989; Lachumy, dkk., 2010)

Alkaloid

Larutan Uji: $500 \mathrm{mg}$ ekstrak ditambahkan $1 \mathrm{ml}$ $\mathrm{HCl} 2 \mathrm{~N}$ dan $9 \mathrm{ml}$ air kemudian dipanaskan di penangas air selama 2 menit, didinginkan dan disaring sehingga diperoleh filtrat.

a.

Pereaksi Bouchardat

Pereaksi: $2 \mathrm{~g}$ iodium dan $4 \mathrm{~g}$ KI dilarutkan dalam 100,0 ml aquades prosedur: $1 \mathrm{ml}$ filtrat ditambahkan 2 tetes pereaksi bouchardat. Jika terbentuk endapan coklat sampai hitam maka mengandung alkaloid.

b. Pereaksi Mayer

Pereaksi : campuran larutan raksa (II) klorida (1,358 $\mathrm{g} \mathrm{HgCl}_{2}$ dalam $60 \mathrm{ml}$ akudes) dengan larutan kalium iodida $(5 \mathrm{~g}$ kalium iodida $\mathrm{P}$ dalam $10 \mathrm{ml}$ akuades) dicukupkan volumenya dengan akuades hingga 100,0 ml. Prosedur: $1 \mathrm{ml}$ filtrat ditambahkan 2 tetes Pereaksi Mayer. Jika terbentuk endapan menggumpal putih atau kuning yang larut dalam metanol maka positif mengandung alkaloid.

c. Pereaksi Dragendorf

Pereaksi : campuran larutan bismuth nitrat (8 g bismuth nitrat dalam $20 \mathrm{ml}$ asam nitrat) dan larutan iodida (27,2 g kalium iodida dalam 50,0 ml akuades) yang didiamkan hingga memisah sempurna. Larutan jernih diambil dan dicukupkan volumenya dengan akuades hingga 100,0 ml. Prosedur: $1 \mathrm{ml}$ filtrat ditambahkan 2 tetes pereaksi Dragendorf, apabila terbentuk endapan jingga coklat maka mengandung alkaloid. Serbuk mengandung alkaloid jika sekurangkurangnya terbentuk endapan dengan dua golongan larutan percobaan yang digunakan.

\section{Terpenoid/Steroid}

$10 \mathrm{mg}$ ekstrak ditambahkan $5 \mathrm{ml}$ eter dan diuapkan di dalam cawan penguap. Residu ditambahkan 2 tetes asam asetat anhidrat dan 1 tetes asam sulfat pekat. Ekstrak mengandung sterol atau terpen apabila terbentuk warna merah-hijau atau violet-biru.

\section{Flavonoid}

Beberapa mg ekstrak ditambahkan $4 \mathrm{ml}$ etanol hingga ekstrak larut.

a. $\quad 2 \mathrm{ml}$ larutan ditambahkan 0,5 gram serbuk

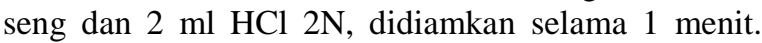
Kemudian ditambahkan 10 tetes $\mathrm{HCl}$ pekat, apabila terbentuk warna merah intensif dalam waktu 2-5 menit menunjukkan adanya flavonoid (glikosida-3flavonol)

b. $\quad 2 \mathrm{ml}$ larutan ditambahkan 0,1 gram serbuk magnesium dan 10 tetes $\mathrm{HCl}$ pekat, apabila terbentuk warna merah jingga sampai merah ungu menunjukkan flavonoid atau kuning jingga menunjukkan adanya flavon, kalkon dan auron.

c. Ekstrak dilarutkan dalam aseton kemudian sedikit serbuk halus asam borat dan serbuk asam oksalat, dipanaskan hati-hati dan dihindari pemansan berlebihan. Sisa dicampur dengan $10 \mathrm{ml}$ eter. Diamati di bawah sinar UV 366 nm, jika larutan berflurosensi kuning intensif menunjukkan adanya flavonoid.

Tanin

Beberapa mg ekstrak kental ditambahkan $15 \mathrm{ml}$ air panas kemudian dipanaskan hingga mendidih selama 5 menit lalu ditambahkan beberapa tetes $\mathrm{FeCl}_{3}$ $1 \%$ menghasilkan hijau violet.

\section{Saponin}

$500 \mathrm{mg}$ ekstrak dimasukkan ke dalam tabung reaksi dan ditambahkan $10 \mathrm{ml}$ air panas, dinginkan dan kocok kuat-kuat selama 10 detik. Terbentuk buih yang mantap setinggi 1 hingga $10 \mathrm{~cm}$ selama tidak kurang dari 10 menit. Pada penambahan 1 tetes $\mathrm{HCl}$ $2 \mathrm{~N}$ buih tidak hilang.

\section{Uji Toksisitas dengan metode BSLT}

Pengujian sifat toksisitas dengan metode BSLT (Brine Shrimp Lethal Test) melalui beberapa tahapan sebagai berikut :

a. Penetasan Larva Udang

Telur udang ditempatkan pada kotak penetasan yang telah diberi air laut secara perlahan sampai setengah dari volume total dan bagian kotak yang berisi telur udang ditutup dengan alumunium foil. Kotak yang telah ditutup ditempatkan di bawah sumber cahaya 5 watt $\left(24-28^{\circ} \mathrm{C}\right)$. Setelah 48 jam, nauplii udang (larva) dikumpulkan menggunakan pipet, kemudian larva $A$. salina siap untuk digunakan pada uji toksisitas (Pisuthanan, dkk., 2004; Rakhmawati, dkk., 2009; Wanyoike, dkk., 2004).

b. Persiapan Larutan yang akan Diuji

Ekstrak dan senyawa murni yang akan diuji dibuat konsentrasi 1000, 500, 100 dan $10 \mu \mathrm{g} / \mathrm{mL}$ dalam air laut, apabila sampel tidak larut tambahkan 2 tetes DMSO (dimetil sulfoksida).

c. Uji Toksisitas Metode Meyer

Larva udang yang hidup sebanyak 10-15 ekor dimasukkan ke dalam vial uji yang berisi $100 \mu \mathrm{L}$ air laut, tambahkan larutan contoh yang akan diuji masing-masing $10,100,500$ dan $1000 \mu \mathrm{g} / \mathrm{mL}$. Larutan diaduk sampai homogen, untuk setiap konsentrasi dilakukan tiga kali pengulangan. Sebagai kontrol dilakukan dengan tidak menambahkan sampel, kemudian didiamkan selama 24 jam, selanjutnya dihitung jumlah larva udang yang mati dan yang masih hidup. Tingkat kematian atau mortalitas dihitung dengan membandingkan antara jumlah larva yang mati dibagi dengan jumlah larva udang.

Dibuat grafik antara log konsentrasi terhadap mortalitas. Nilai $\mathrm{LC}_{50}$ didapat dengan cara menarik garis pada nilai $50 \%$ dari sumbu mortalitas sampai memotong sumbu grafik, perpotongan garis ditarik ke garis konsentrasi dimana zat menyebabkan kematian $50 \%$ larva yang disebut $\mathrm{LC}_{50}$. Suatu zat dikatakan aktif atau toksik bila nilai $\mathrm{LC}_{50} \leq 1000 \mu \mathrm{g} / \mathrm{mL}$. (Meyer, 1982). 


\section{HASIL DAN PEMBAHASAN}

Tumbuhan merupakan sumber senyawa bioaktif yang penting untuk pengembangan agen terapetik baru. Sudah banyak yang melaporkan mengenai sifatsifat anti bakteri, antivirus, antijamur dari berbagai tumbuhan (Lachumy, dkk., 2010). Oleh karena itu, pengamatan tersebut membantu untuk mengembangkan obat baru sebagai agen terapetik. Akan tetapi, penelitian mengenai bioaktivitas dari $M$. fatua masih sedikit dan belum ada yang melakukan studi mengenai penapisan fitokimia dan efek toksisitas terhadap larva udang $A$. salina dari daun Myristica fatua. Oleh karenanya, kami melaporkan hasil penapisan fitokimia dan uji toksisitas dari daun M. fatua.

Pada penelitian ini, ekstrak metanol daun $M$. fatua diuji secara kualitatif kandungan golongan senyawa tanin, alkaloid, terpenoid, flavonoid dan saponin yang dapat dilihat pada Tabel 1. Dari hasil skrining fitokimia tersebut ekstrak metanol mengandung terpenoid/steroid, flavonoid, dan tanin (fenolik).

Uji BSLT dilakukan terhadap ekstrak metanol, etanol $70 \%$ dan aseton, sebagai kontrol dipergunakan air laut yang tidak ditambahkan sampel. Metode uji toksisitas ini dilakukan karena biayanya murah dan hasilnya dapat dipercaya (Lachumy, et al., 2010). Pada uji ini diamati adalah tingkat mortalitas yang disebabkan oleh senyawa uji. Menurut Meyer, et al.,
1982, senyawa aktif akan menghasilkan mortalitas yang tinggi, senyawa dengan $\mathrm{LC}_{50} \leq 1000 \mu \mathrm{g} / \mathrm{mL}$ dapat dikategorikan sebagai senyawa yang mempunyai potensi sebagai senyawa yang bersifat toksik, semakin kecil nilai $\mathrm{LC}_{50}$ nya maka senyawa tersebut dikatakan semakin aktif/toksik. Hasil uji BSLT dapat dilihat pada Tabel 2.

Tabel 1. Penapisan fitokimia ekstrak metanol daun Myristica fatua

\begin{tabular}{clc}
\hline No. & \multicolumn{1}{c}{ Jenis uji } & Hasil uji \\
\hline 1 & Terpenoid/Steroid & ++ \\
2 & Alkaloida & - \\
3 & Flavonoida & + \\
4 & Saponin & - \\
5 & Tanin & +++ \\
\hline
\end{tabular}

Keterangan :

Tanin : (+) terbentuk warna hijau kehitaman

Flavonoida : (+) terbentuk warna kuning jingga

Saponin : (+) terbentuk buih stabil

Terpenoid/Steroid: $(+)$ terbentuk warna merah-hijau

Berdasarkan Tabel 2, ekstrak metanol daun $M$. fatua menunjukkan $\mathrm{LC}_{50}$ paling kecil (paling toksik) dibandingkan ekstrak etanol $70 \%$ dan aseton sehingga ekstrak metanol difraksinasi lebih lanjut dengan ekstraksi cair-cair bertingkat berdasarkan kepolaran menggunakan pelarut $n$-heksana, etil asetat dan $n$ butanol. Hasil uji dari fraksi-fraksi terrsebut dapat dillihat pada Tabel 3 .

Tabel 2. Analisa hasil Brine Shrimp Lethality Test (BSLT) dari ekstrak metanol, etanol $70 \%$ dan aseton dari daun $M . F$. fatua

\begin{tabular}{llllll}
\hline No & Sampel Daun M. fatua & Konsentrasi (K), ppm & Log K & Mortalitas & LC $_{\mathbf{5 0}}$ \\
\hline 1 & Ekstrak Metanol & 5 & 0,7 & 3,33 & \\
& & 10 & 1 & 13,04 & 64,57 \\
& & 50 & 1,7 & 35,14 & \\
2 & \multirow{4}{*}{ Ekstrak Etanol 70\% } & 100 & 2 & 66,67 & \\
& & 10 & 1 & 1,61 & \\
& & 500 & 2 & 10,64 & $>1000$ \\
3 & \multirow{2}{*}{ Ekstrak Aseton } & 1000 & 2,7 & 29,73 & \\
& & 10 & 3 & 61,29 & \\
& & 100 & 1 & 13,24 & \\
& & 500 & 2 & 35,59 & 141,25 \\
& & 1000 & 2,7 & 66,10 & \\
\hline
\end{tabular}

Tabel 3. Analisa hasil Brine Shrimp Lethality Test (BSLT) dari fraksi $n$-heksana, etil asetat, dan $n$-butanol dari daun $M$. fatua

\begin{tabular}{llllll}
\hline No & Sampel Daun $\boldsymbol{M}$. fatua & Konsentrasi (K), ppm & $\mathbf{L o g} \mathbf{K}$ & Mortalitas & LC $_{\mathbf{5 0}}$ \\
\hline 1 & Fraksi $n$-heksana & 10 & 1 & 10,15 & \\
& & 100 & 2 & 31,58 & 153,108 \\
& & 500 & 2,7 & 60,00 & \\
2 & \multirow{4}{*}{ Fraksi etil asetat } & 1000 & 3 & 96,67 & \\
& & 10 & 1 & 6,25 & \\
& & 500 & 2 & 53,85 & 83,75 \\
3 & \multirow{2}{*}{ Fraksi $n$-butanol } & 1000 & 2,7 & 88,46 & \\
& & 10 & 3 & 98,68 & \\
& & 100 & 1 & 15,00 & \\
& & 500 & 2 & 46,43 & 100,93 \\
\hline
\end{tabular}


Pada Tabel 3 di atas dapat dilihat bahwa fraksi etil asetat mempunyai nilai $\mathrm{LC}_{50}$ paling kecil dibandingkan fraksi $n$-heksana dan $n$-butanol, yang dapat diilustrasikan pada Gambar 1 di bawah ini. Oleh karenanya, fraksi etil asetat dengan nilai $\mathrm{LC}_{50} 83,75$ $\mu \mathrm{g} / \mathrm{mL}$ dapat dikembangkan lebih lanjut sebagai antitumor/anti kanker (Singh, dkk., 2015). Akan tetapi, fraksi $n$-heksana dan $n$-butanol juga mempunyai efek toksik yang cukup baik dengan $\mathrm{LC}_{50}$ $<1000 \mu \mathrm{g} / \mathrm{mL}$.

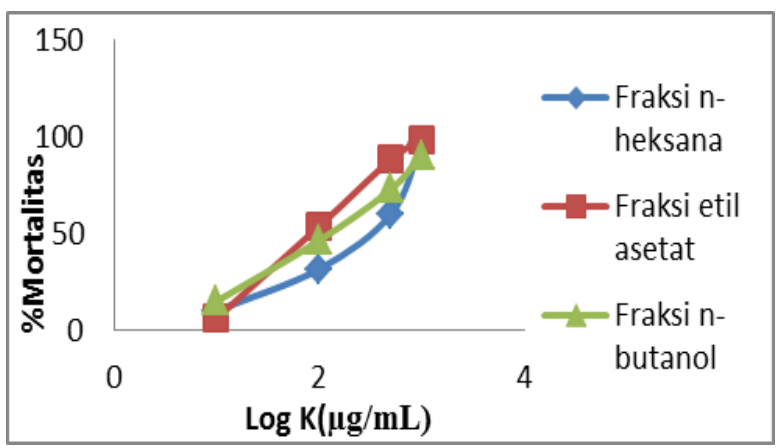

Gambar 1. Grafik hasil uji toksisitas dengan metode BSLT dari fraksi $n$-heksana, etil asetat, dan $n$-butanol dari daun $M$. fatua Houtt

\section{KESIMPULAN}

Hasil skrining fitokimia dari ekstrak metanol daun Myristica fatua Houtt mengandung terpenoid/steroid, flavonoid, dan tanin (fenolik). Berdasarkan hasil uji toksisitas menggunakan metode BSLT, ekstrak metanol dan fraksi etil asetat mempunyai efek toksik yang paling tinggi dibandingkan ekstrak dan fraksi lainnya sehingga berpotensi untuk dikembangkan sebagai antitumor atau antikanker.

\section{UCAPAN TERIMA KASIH}

Kami mengucapkan terimakasih kepada kegiatan Mandiri Pusat Penelitian Kimia LIPI dan Indonesia Toray Science Foundation yang telah membiayai penelitian ini. Kami juga mengucapkan terimakasih kepada Dr. Akhmad Darmawan atas diskusi mengenai penelitian dari tumbuhan Myristica fatua di Indonesia.

\section{DAFTAR PUSTAKA}

Arrijani. (2005). Review: Biologi dan Konservasi Marga Myristica di Indonesia. Biodiversitas, 6 (2), 147-151.

Depkes RI. (1989). Materia Medika Indonesia, Jilid $V$. Jakarta: Departemen Kesehatan Republik Indonesia. 549-553.

Jamal, Y \& Agusta, A. (2004). Komposisi Kimia Minyak Atsiri Pala Wegio (Myristica fatua Houtt), Berita Biologi, 3, 155-158.

Lachumy, S.J.T., Sasidharan, S., Sumathy, V. \& Zuraini, Z. (2010). Pharmacological activity, phytochemical analysis and toxicity of methanol extract of Etlingera elatior (torch ginger) flowers, Asian Pasific Journal of Tropical Medicine, 769774.

Meyer, B.N., Ferrigni, N.R., Putnam, J.E., Jacobsen, L.B., Nichols, D.E. \& McLaughlin, J.L. (1982). Brine shrimp: a convenient general bioassay for active plant constituents. Planta Medica, 45, 3134.

Pisutthanan, S., Plianbangchang, P., Pisuthanan, N., Ruanruay, S. \& Muanrit, O. (2004). Brine Shrimp Lethality Activity of Thai Medicinal Plants In the Family Meliaceae, Naresuan University Journal, 12(2), 13-18.

Rakhmawati, R., Anggarwulan, E. \& Retnaningtyas, E. (2009). Potency of Lobak Leaves (Raphanus sativus L. var. hortensis Back) as Anticancer and Antimicrobial Candidates, Biodiversitas, 10, 158162, ISSN: 1412-033X.

Singh, G.S., Al-Kahraman, Y.M.S.A., Mpadi, D. \& Yasinzai, M. (2015). Synthesis, Antimicrobial, and Brine Shrimps Lethality Assays of 3,3Diaryl-4-(1-methyl-1H-indol-3-yl)azetidin-2ones, J. Heterocyclic Chem, 52, 614.

Wanyoike, G.N., Chhabra, S.C., Lang'at-Thoruwa, C.C. \& Omar, S.A. 2004, Brine shrimp toxicity and antiplasmodial activity of five Kenyan medicinal plants, Journal of Ethnopharmacology, 90, p:129-133. 